\title{
Assessing natural vs anthropogenic horizons through deposit modelling strategies at the Medieval Site of Santa Margarida (Martorell, Barcelona, Spain)
}

Esther Travé Allepuz ${ }^{1,2}$; Josep Maria Tella Ros ${ }^{2,3}$; Pablo Del Fresno Bernal ${ }^{4}$; Josep Socorregut Domènech $^{4}$; Alfred Mauri Martí ${ }^{2}$

\author{
${ }^{1}$ Universitat de Barcelona, Department of History and Archaeology, Barcelona, Spain \\ ${ }^{2}$ Centre d'Estudis Martorellencs, Martorell, Barcelona, Spain \\ ${ }^{3}$ TERRES SL. Laboratori de Ciències de la Terra, Martorell, Barcelona, Spain \\ ${ }^{4}$ Sistemes de Gestió de Patrimoni SCCL, Barcelona, Spain
}

\section{Correspondence}

Esther Travé Allepuz, Universitat de Barcelona, Department of History and Archaeology, C/Montalegre 6, 08001, Barcelona, Spain. Email: esther.trave@ub.edu

\begin{abstract}
Geophysical surveys have been one of the most useful tools for non-invasive archaeological field assessment. Whereas they have been regularly put into practice at the archaeological site of Santa Margarida (Martorell, Barcelona, Spain), the particular features of the site required a more specific strategy in order to identify the contact interface between anthropogenic and natural deposits and, therefore, to conclude the archaeological excavation. As the archaeological site is settled on Quaternary alluvia at the confluence of two rivers, and in the absence of built structures in some areas, it was extremely difficult to distinguish between anthropic layers and those silty or sandy natural deposits during fieldwork. Extensive soil survey by means of borehole logging, full-coring, and DPSH testing within this site has proved to be a useful strategy to identify the geological horizon and to map the original relief of past landscape prior to excavation tasks. This enabled us to plan our fieldwork better and to interpret particular features of the site. This paper aims at summarizing the results of recent surveys, and discussing the potential of this approach for the study of rural settlements and agrarian landscapes in the Middle Age.
\end{abstract}

Keywords Soil stratigraphy, Deposit modelling, Field survey, Landscape, Fieldwork scheduling, Mapping

This is a preprint.

How to cite this article:

Travé Allepuz, E., Tella Ros, J. M., Del Fresno Bernal, P., Socorregut Domènech, J., Mauri Martí, A. Assessing natural versus anthropogenic horizons through deposit modelling strategies at the Medieval Site of Santa Margarida (Martorell, Barcelona, Spain). Geoarchaeology. 2021; 1-21. https://doi.org/10.1002/gea.21844 


\section{INTRODUCTION}

The geoarchaeological approach, broadly understood as the application of geosciences to solve research problems in archaeology (Pollard, 1999: 7; Wilson 2011: 2, Kokinou, 2015: 209), is a longlasting consolidated practice in the archaeological domain for multiple research purposes. In the last fifty years, the finding and location of archaeological sites has considerably benefited from the advances in geophysical survey techniques, which has enhanced the design and planning of archaeological excavation in a more cost-effective way. Non-intrusive methods such as groundpenetrating radar, electromagnetic induction methods, electrical resistance techniques, and magnetic or acoustic assessment, among some other less frequent practices (Sarris et al., 2018: 224-226), have been crucial for site exploration and mapping. The archaeological project of Santa Margarida (Martorell, Barcelona, Spain) has pioneered the geoarchaeological approach in Catalonia since it began in the eighties (Mauri, 1988: 8-10; Farreny et al., 2012: 368).

The site of Santa Margarida is settled on a Quaternary alluvial plain at the confluence of two rivers. The most evident vestige is a Romanesque temple built upon the structure of an Early Christian church, and surrounded by an extensive necropolis as well as habitat and storage structures. After more than forty years of archaeological fieldwork, excavation tasks apparently concluded in some areas when artefact-lacking clayey layers were reached and attributed to the alluvial natural deposits. However, more recent excavations -planned according to ground-penetrating radar (GPR) survey results (Sala et al., 2010 \& 2011)- revealed that some of those deposits were in fact abandonment layers covering earlier occupation horizons. Certainly, in the absence of built structures or artefacts in some areas, it was extremely difficult to distinguish between anthropogenic layers and those silty or sandy natural deposits during fieldwork. The issue of archaeological 'non-visibility' (Campana, 2009) became then a major challenge for archaeological investigation at the site and fostered the search for other strategies in order to determine whether the excavation tasks could be concluded or not and to explore the archaeological potential of adjacent areas.

The main research problem to solve was the correct identification of the natural horizon after removing the archaeological deposits and artificial ground. Distinguishing this geological interface between clayey and silty layers with extremely feeble human evidence (or none at all) required a more precise assessment of the geological environment features, for which some proposals have been made in the past. Existing literature on this topic (Kokinou, 2015: 210-211; David et al., 2008; Carey et al., 2019: 498-499; Layzell \& Mandel, 2019; Artz, 2006) demonstrates how a combined approach using geophysical techniques in conjunction with a borehole sampling can provide a cost-effective methodology for modelling subsurface stratigraphy (Bates \& Bates, 2000: 845).

Extensive soil survey by means of combined borehole logging, Dynamic Penetrometer Super Heavy (DPSH) testing, and undisturbed sample full coring and analysis within this site has proved to be a useful strategy to identify the geological horizon and to map the original relief of past landscape prior to excavation tasks in new trenches. This enabled us to plan our fieldwork better and to interpret particular features of the site. This paper aims at summarizing the results of recent surveys, and discussing the potential of this approach for the study of rural settlements and agrarian landscapes in the Middle Age.

In fact, by means of analysing the results obtained at Santa Margarida, we aim at offering some thoughts about the relation between environmental features and settlement history, and about the way in which geological conditions at the site are concomitant with postdepositional affectation of archaeological vestiges as well. By sharing our study case results with a broad audience throughout this paper, and discussing the pros and cons of our strategy, we might help other archaeologists in the need of determining accurately the natural horizon distinction at their sites from a geoarchaeological approach.

Furthermore, the research problems identified at the medieval rural site of Santa Margarida are particularly common to many other sites from the medieval period. Our contribution also aims at introducing new experiences and approaches in the domain of Medieval Archaeology in order to deal with common difficulties in the research on this period. Increasingly often, the valuable contribution of geosciences provides new insights for the investigation on medieval landscapes (Quirós-Castillo \& 
Nicosia, 2019), and offers new and more complete datasets for the examination of agricultural activities and their occasional influence on earlier vestiges. Accordingly, results obtained at Santa Margarida can also be discussed in terms of peasant agency, human settlement and the construction of medieval landscapes under the influence of feudal social structures.

\section{MATERIALS AND METHODS}

\subsection{The archaeological site}

The archaeological site of Santa Margarida (Barcelona, Spain) is located in the municipality of Martorell, at the confluence of rivers Llobregat and Anoia, and on the ancient Roman road known as Via Augusta, on its way from the Roman city of Barcino to the capital Tarraco. Since the Roman period, Martorell has been a neuralgic nodal point and a crossroads between the area of Barcelona and the Catalonian inlands out of the influence of the coastal area. Still today, the AP-7 motorway follows the itinerary of the Via Augusta's route some $50 \mathrm{~m}$ away from the archaeological site (Figure 1a-c).

First permanent settlement is evidenced by a $5^{\text {th }}$-Century-AD Early-Christian church with a tripartite apse and its extensive necropolis surrounding the temple (Navarro \& Mauri, 1993). A horseshoearched entrance on the South wall leads to an annexe hall building, probably used for funerary purposes. Another attached building on the West wall might have been used as a baptisterium. These annexe buildings did not last for a long time, as the burials of the Early Christian Necropolis $\left(5^{\text {th }}-7^{\text {th }}\right.$ Centuries AD) were arranged in order around the temple once they had already been demolished (Figure 1d). During the period between the $6^{\text {th }}$ and the $12^{\text {th }}$ Centuries, the site experienced a great transformation in accordance to the origin and early development of the medieval village of Martorell and the successive refurbishment of the church, finally transformed into a Romanesque building (Navarro \& Mauri, 1993: 342; Travé et al., 2019: 186).

During the second half of the $11^{\text {th }}$ Century AD, while the Early Christian church was still in use, some medieval cob-built habitat structures were placed in the nearby area. Within an adjacent radius of 30 feet around the church, peasants were protected against the feudal landlords' violence during the $10^{\text {th }}$ and the $11^{\text {th }}$ Centuries. This so-called sacraria or sacred area provided a safer place to live, and a great number of silos for grain storage were discovered together with the houses. At this moment, the neighbouring monastery of Sant Genís de Rocafort was built on the top of a hill at the Northwestern slope of the Ataix Mountains, and Santa Margarida became the parish church depending on the monastery (Figure 1c). At the end of the $12^{\text {th }}$ Century, the parish was in a blossoming period and the Early Christian building was partially demolished to build up a new Romanesque church (Figure 2ab). From this moment on, the archaeological sites of Santa Margarida and Sant Genís would share a common history.

Archaeological research had focused on the church building and its closest $750-\mathrm{m}^{2}$-wide area, until we enlarged the excavation trench in 2012. Since then, extensive excavation of a $1500-\mathrm{m}^{2}$-wide area has allowed us to gain a better insight of the habitat structures around the church and their chronology, but it has also raised new research questions regarding the landscape structure and layout. Preliminary results show alternative periods of habitat and funerary uses (Travé et al., 2019: 184-185). There are up to three building phases, the latest one related to a piping channel, and some of these buildings reuse those of the earlier period slightly changing their orientation (Figure 2c). Plenty of silos pierce the occupation and burial horizons and provide chronological reference, due to the abundance of pottery sherds within their filling deposits (Navarro \& Mauri 1997: 95; Travé et al., 2019: 186-187).

The site was occupied and exploited as a farm until the first half of the $20^{\text {th }}$ Century. This continuous occupation provides a complete diachronic sequence of burial practices for the late antique, medieval, modern and contemporary eras, but it also affects the visibility of remains from the earliest periods. Certainly, many researchers in Western Europe and the Mediterranean (Francovich, 2004; QuirósCastillo, 2011: 380; Vigil-Escalera, 2010: 1; Reynolds 2003) have addressed the problem of 'nonvisibility' of archaeological vestiges in specific contexts -the early medieval centuries being one of those scenarios-. As a matter of fact, there is a strong relationship between visibility and continuity of settlement, as enduring occupation of the same location interrupts ancient deposits and features, 
together with agricultural activity (Schofield, 1991), which also has an impact on subsurface deposits (Campana, 2009: 8-10).

Geological context of this site has also challenged the archaeological work (Figure 3). Martorell is located in the geological depression of Vallès. This depression is a long corridor that follows a SWNE direction and extends in parallel to the Mediterranean Coast. The Coastal Mountain Range at the East and the Pre-Coastal Mountain Range at the West frame this lowland, through which the Anoia river tributes its water flow to the Llobregat. The geological fault was formed during the Alpine orogeny (Oligocene - Miocene), and tectonic and sedimentary layout dives to the NW about $15^{\circ}-20^{\circ}$ with local variations. Our area of interest is located on the northern slope of the Coastal Mountain Range (Serra de l'Ataix), at the right shore of the Anoia river. The region features Ordovician-Silurian metamorphic outcrops (sericite-rich slate and phyllite) and granite intrusions mostly covered by Triassic (Buntsandstein) and Miocene fine-grained sedimentary rocks. These are reddish sandstones, and some conglomerate alternating with abundant claystone or siltstone. Palaeozoic/Triassic basement and Miocene materials are in contact along the fault line. Covering these materials, the alluvial plain of rivers consists of grain-classified layers. Gravel strata at the bottom alternate with sandy layers and clayey silt or silty clay on the top.

This area has a Mediterranean climate with pleasant winters and warm summers. Medium temperature average in winter is $3^{\circ} \mathrm{C}$ to $13^{\circ} \mathrm{C}$, while summer temperatures easily reach $30^{\circ} \mathrm{C}$ and do not get below $19^{\circ} \mathrm{C}$ in the cooler hours of the day. Medium annual precipitation oscillates between seasons. Spring and autumn concentrate the maximum rainfall, around $41 \mathrm{~mm}$ in May and $57 \mathrm{~mm}$ in October. The Anoia river is an eloquent exponent of secondary waterflows in the Mediterranean coast. Its perennial drainage -despite being low- decreases significantly in the driest seasons of summer and the core of winter and increases considerably in spring and autumn when the rainfalls are more severe. The junction between Anoia river as a tributary to the Llobregat basin has formed along geological history of this site up to four terraces in some areas.

\subsection{Survey areas and deposit modelling methods}

The archaeological site is part of the municipal land property, close to the local cemetery and enclosed by a fence. The access path to Santa Margarida runs in parallel to the motorway leading to the urban nucleus and in perpendicular to the path to the cemetery, which leads to a local road to the town (Figure 4). Geophysical GPR surveys carried out in the past were always limited to the archaeological area inside the fence and have regularly provided valuable information about the subsurface features (Sala et al., 2011), later corroborated by the archaeological excavation (Travé et al., 2019: 182).

As stated above, as long as the fieldwork progressed, a yellowish artefact-free clayey layer was uncovered in some of the areas, which initially led us to conclude that the archaeological tasks were completed there. Prior to the trench enlargement in 2012, a geological borehole logging survey was carried out inside the site's fence in order to determine the archaeological potential of the area by identifying the anthropogenic layers and distinguishing the interface's relief between the packages of anthropogenic sediment and the original alluvium. In 2011, a sum of twelve 10-cm-in-diametre boreholes were logged and a selection of core samples was obtained for further lab examination, as detailed in table 1. Those areas where GPR-detected anomalies were more imprecise or confusing were selected for logging, and selected core samples were extracted as cylindrical sections by drilling with a ring-lined barrel sampler (ASTM D3550, 2017). Archaeological investigation has demonstrated that the archaeological vestiges of habitat structures continue to the east, out of the municipal land property, but we did not know what happened in the subsurface to the west. Enclosed by the paths leading to the town, there is a $12000-\mathrm{m}^{2}$ area of pine forest and ground vegetation. The area was presumed to have archaeological potential but -being densely wooded-the use of common geophysical non-intrusive methods probably would not have led to reliable data (Sarris et al., 2018, 231-232). Deposit modelling (Carey et al., 2017 \& 2019) carried out in 2011 produced successful results, which led us to plan a more extensive survey outside the site's limit, and 25 same-size boreholes were logged in the forest.

Boreholes from inside the archaeological site were correlatively numbered from 1 to 12 . Boreholes in the external surveyed area were also numbered correlatively from 1 to 25 . Subscript labels reading 'in' or 'out' attached to the borehole number indicated the survey area of each one of them. Visual 
description of sediments and soils was carried out constantly while drilling in both areas, which provided direct information about the subsurface sediment architecture and stratigraphy (Carey et al., 2019: 498; Artz 2006: 20). Full coring was performed at different depths and 59 non-altered 60-cmlong cores were sampled and lab-analysed.

These analyses included sample sieving and plasticity index calculation for the fraction passing 425 $\mu \mathrm{m}$ sieve. Obtained results allowed us to classify samples within standard geotechnical soil groups (García-Gaines \& Frankenstein, 2015; Burmister, 1949) according to particle size determination (PSD) and plasticity index by Attenberg limits identification (Rząsa \& Owczarzak, 2013; Kettler et al., 2001), following the Highway Research Board (HRB) Classification of Soil (HRB, 1952) and the Unified Soil Classification System (USCS) (Casagrande, 1949). Tables 2 and 3 summarize the main abbreviation and definitions for soil classification used throughout the results section in this paper. Volumetric relations according to weight, density, porosity and saturation were also established for all samples studied, together with chemical determination of organic matter and $\mathrm{CaCO}_{3}$ percentages by attacking samples with hydrogen peroxide and hydrochloric acid respectively. The data obtained allowed us to determine stratigraphic columns and compare them for deposit modelling, represented by several cross-sections at the site and interface isoline maps (Carey et al., 2019: 503). Soil resistance in the external surveyed area was complementarily tested in nine of the boreholes by means of dynamic probing test (MacRobert et al., 2011; MacRobert 2017, Spagnoli, 2007). Comparing DPHS penetration values against the deposit modelling obtained provided further information about the depth and features of anthropogenic strata. Table 1 summarizes the main contextual data of all the samples analysed.

\section{RESULTS}

Two superposed major packages of sediment -anthropogenic and natural- have been detected in the entire prospected area, even though the stratigraphic sequence and palaeorelief exhibits some variation between the enclosure of the archaeological site and the external surveyed area. The results obtained enabled us to identify three correlated stratigraphic columns, one of them illustrating the stratigraphic sequence of the external surveyed area -usually more homogeneous- and the other two representing the southern and northern area of the archaeological site according to a significant variation in the ancient landscape. In these columns we represent the depth of sediment packages according to the medium average depth of strata for each group of boreholes included (Figure 5).

\subsection{Deposit modelling and soil classification}

Geomorphological environment at this site illustrates the most common features of alluvial landscapes. Below the anthropogenic deposits, materials from the lower quaternary terrace are formed by pale brown silt, occasionally with carbonates related to the recent Holocene floodplains, with a buried landsurface on the top. Occasionally, the transition between the anthropogenic and the natural layers is difficult to distinguish, so that the interface is not so clear. This usually happens when the natural silt or fine clay of the quaternary floodplain appears removed and mixed with the anthropogenic lower level. At a deeper level, these silty layers turn into sandy or gravely strata related to the middle Pleistocene terrace. This terrace reaches higher elevation below the farm-building (Figure 4) adjacent to the site.

Granulometric analysis of these sediments reveals a uniform particle size distribution (PSD), particularly for the lower terrace (Figure 6a), showing well or very well sorted unimodal silt with slight variations (trends Q1-a to Q1-c). This distribution graph predominantly takes into account data gathered at the external surveyed area, where boreholes only penetrated the top layer of natural stratigraphy. Soil humidity has values between 5 to $10 \%$, and dry density oscillates from 1.58 to $1.72 \mathrm{t} / \mathrm{m}^{3}$. Soil classification is SM according to USCS, and A-4 to A-2-4 according to HRB for trend Q1-a; and CL/A4 for trend Q1-b, and SM(ML)/A-4 for trend Q1.c. These are mostly non-plastic layers with low content of organic matter $(0.5-1.0 \%)$ and variable $\mathrm{CaCO}_{3}$ content, usually from $1-6 \%$ and exceptionally above $11 \%$ in samples $19 / 17$ and $11 / 11$. 
In contrast, deeper borehole logging inside the archaeological site's enclosure revealed the alternation of more silty to more gravely layers, reflecting different river terraces and flooding episodes. These layers exhibit coarser and bimodal PSD, particularly for sample 11/06, attributed to the middle terrace $(\mathrm{Qm})$, according to its entire borelog. Among these samples, granulometric trends (Q1-e to Q1-f) are more heterogeneous as outlined in PSD graphs (Figure 6b). Differences in PSD, reflected in soil classification -CL, CL-ML, ML, or SM according to USCS, and A-4 (rarely A-6) according to HRBhave a good correlation with organic matter and $\mathrm{CaCO}_{3}$ contents, which certainly points towards the existence of different strata within the medium and lower Quaternary terraces. Finer-grained and better-sorted sediments of samples 2011/12 and 17 in trend Q1-d have higher $\mathrm{CaCO}_{3}$ content $(>12 \%)$, except for sample 2011/15, with lower content below $2 \%$, while percentages of $\mathrm{CaCO}_{3}$ in trend Q1-e oscillate between 5-9\%. One loner sample reflecting granulometric trend Q1-f contains unimodal and moderately sorted medium-to-fine silt including $10.1 \%$ of $\mathrm{CaCO}_{3}$ and $1.1 \%$ of organic matter. Organic matter content also has good correlation with soil classification. It is $<2 \%$ in trend Q1-d and $>2 \%$ in trend Q1-e. Dry density oscillates between 1.58 and $1.80 \mathrm{t} / \mathrm{m}^{3}$ in all samples. They are non-plastic or slightly plastic except for samples 2011/01 and 02, with higher indexes above 8.8. In accordance, we suggest that these samples correspond to Pleistocene terraces. Coarser fractions of Quaternary deposits are rather uniform; they contain rounded pebbles and carbonated gravel grains. Anthropic materials are insignificant or absent throughout these strata.

Non-surprisingly, anthropogenic deposits are far more complex. A varied assemblage of filling ground, farmland, cobblers and blocks, ceramic sherds, mortar and concrete portions, plastics, or iron fragments is common in the most superficial layers. Below them, recent survey in the external area carried out in 2019 revealed the existence of a stratigraphic sequence (see the stratigraphic column for boreholes $1_{\text {out }}$ to $20_{\text {out }}$ in figure 5) alternating layers of three major packages of sediment (labelled as A, B, C) and vegetal soils $(\mathrm{H})$. The present-day soil at the surface $\left(\mathrm{H}_{1}\right)$, usually reaches $0.20-0.25 \mathrm{~m}$ in depth and seals the subsurface layers. Within the alternation of strata, there are two additional levels of ancient vegetal soil $\left(\mathrm{H}_{2}\right.$ and $\left.\mathrm{H}_{3}\right)$, spreading variably and discontinuously throughout the surveyed area. The deepest and earliest vegetal soil $\left(\mathrm{H}_{3}\right)$ covers the interface between anthropogenic and natural deposits. It is poorly preserved, and it is only present in some restricted areas.

Strata $A_{1}$ and $A_{2}$ consist of unimodal or slightly bimodal pale brown silt and clay, occasionally with some gravel or cobbler inclusions. The coarser fraction includes predominant whitish or semitransparent quartz or garnet-coloured angular sandstone and claystone fragments, common metamorphic fragments of slate or schist, coal inclusions, altered golden biotite with hexagonal exfoliation and mollusc shell (cf. Cepaea) and rare carbonate concretions. Anthropic artefact inclusions such as pottery sherds or mortar fragments are present as well. Despite stratum $\mathrm{A}_{2}$ looking slightly redder, there are no other visual differences of significance between layers $A_{1}$ and $A_{2}$, apart from the stratigraphic disposition of layer $A_{1}$ lying c. $0.1 \mathrm{~m}$ deep, and $A_{2}$ at $0.5 \mathrm{~m}$ below the surface. PSD provides further information about these layers and their granulometric trends (Figure 7a). Samples in stratum $A_{1}$ are coarser and poorly sorted. The core group of samples $\left(A_{2}-a\right)$ from layer $A_{2}$ is very poorly sorted with abundant content of coarse pebbles and sand within a polymodal PSD, while samples included within the trend $\mathrm{A}_{2}$-b are better sorted and show clearly unimodal PSD of predominant silt. Despite this, humidity values between 5\% and 9\% are homogeneous amongst the samples, occasionally reaching $10 \%$ in the deepest levels. Dry density oscillates between 1.63 and 1.81 $\mathrm{t} / \mathrm{m}^{3}$ and there are not any significant variations between $\mathrm{A}_{1}$ and $\mathrm{A}_{2}$. Soil classification is usually ML (CL-ML) and occasionally SM according to USCS; and A-4 or A-2-4 -exceptionally A-6 in sample 2019/39- according to HRB. Percentages of organic matter are highly variable, with an average value of $1.5 \%$ in layer $A_{1}$ and c. $2 \%$ in layer $A_{2}$, within a wide value range between $0.4-4.2 \%$. Higher percentages correlate to those samples closer to the vegetal soils or in contact with them. Carbonate content oscillates between $4 \%$ and $15 \%$.

Strata $\mathrm{B}_{1}$ and $\mathrm{B}_{2}$ include dark brown or reddish clay and clayey silt mixed with sand and medium polygenic gravel. The coarser fraction does not differ at all from that of the sediments in package A. PSD and soil classification allows us to distinguish between both layers, which are thinner and located at 1.2 and $2 \mathrm{~m}$ below the surface level respectively. Stratum $\mathrm{B}_{1}$ includes slightly coarser and polymodal samples, sample $19 / 28$ being a loner that contains a rough $25 \%$ of coarse pebbles (Figure $7 \mathrm{~b}$ ). Stratum 
$\mathrm{B}_{2}$ has unimodal distribution except for sample 19/13 whose bimodal and clayey silt is mixed with $15 \%$ of very coarse pebbles. Sample 19/37 within this group is a very well sorted loner according to PSD. Humidity is variable across the samples, but values do not correlate well with grain-size classification. It is higher at the deepest layers and oscillates between $5-10 \%$, occasionally reaching percentages between $10-13 \%$. Other variables analysed also exhibit a heterogeneous range of values: Dry density is $1.51-1.85 \mathrm{t} / \mathrm{m} 3$; organic matter percentages are between $0.5-5 \%$, exceptionally reaching 9.3\% in sample 2019/28; and carbonate content oscillates between $2-20 \%$.

Between layers $A_{2}$ and $B_{2}$ there is a stratum $C$ of sand and medium-to-coarse pale-brown silt, very homogeneous and well sorted at a depth of $1.8 \mathrm{~m}$. Samples from this layer exhibit unimodal PSD (Figure 7c) and they are classified as SM-ML soils according to USCS and A-4 or A-4 close to A-2-4 according to $\mathrm{HRB}$. Level $\mathrm{C}$ is the richest in $\mathrm{CaCO}_{3}$ content $(14.3-16.8 \%)$ and is relatively poor in organic matter $(0.4-1.2 \%)$. The main features of this coarser fraction do not differ from layers A and B.

Inside the site's enclosure, borehole logging carried out in 2011 revealed a heterogeneous repertoire of anthropogenic deposits (Ad) (Figure 5). In those areas where the quaternary terraces are deeply buried (boreholes $5_{\text {in }}-12_{\text {in }}$ ), the archaeological stratigraphy is obviously very complex and requires a unit of smaller scale (Stein 1990: 520), as per the archaeological record. It seemed pointless to get into much detail and extract a high amount of sediment cores within the archaeological area, regularly surveyed by other non-invasive methods as GRP prior to extensive excavation. Rough description of main sediment packages includes dark-brown sandy layers of low consistence occasionally mixed with gravel (Ad1 \& Ad3), and angular gravel layers (Ad2 \& Ad4). Coarser sediments were frequently spread across the middle quaternary terrace (Ad3 \& Ad4) for levelling and building purposes as demonstrated by archaeological works (Travé et al., 2019). These superficial strata are usually $0-0.5$ $\mathrm{m}$ deep below the present-day vegetal soil surface. In the south, the remains of the Quaternary middle terrace appear immediately below these levels, but, as we move north, the sediments of the lower terrace outcrop below 2 or $2.5 \mathrm{~m}$ deep and there is a considerable package of anthropogenic deposits above them, where most of the archaeological remains are. Dark-brown non-consistent strata of silt and fine sand, with occasional gravel, pottery sherds, carbonaceous inclusions and mortar fragments, generally feature the complex archaeological stratigraphy of deposits in Ad5 at a depth of $0.5-1.5 \mathrm{~m}$. In some areas, additional 1-m-thick deposits of fine (Ad6) or poorly sorted (Ad7) sand mixed with polygenic and angular gravel inclusions form another layer upon the interface between anthropogenic and natural strata at a depth of $1.5-2.5 \mathrm{~m}$.

Only a few samples of these deposits have been analysed and the results are highly heterogeneous, as expected. PSD and complementary analyses of selected samples from Ad reveal the strong variety of archaeological stratigraphy in this area. These are the coarsest of all the characterized assemblages and show a strong polymodal PSD (Figure 7d). Percentages of organic matter $(1.4-1.8 \%$, and exceptionally $2.9 \%)$ and $\mathrm{CaCO}_{3}(8.72-15.51 \%$, usually with values $>10 \%)$ show a string variability as well. Table 4 summarizes the main features of the stratigraphic layers described above including basic classification data and description of each unit.

\subsection{Soil penetration resistance}

Complementary dynamic probing tests at nine points on the external surveyed area evidenced that soil resistance to penetration is higher in anthropogenic deposits. DPSH blow count graphs of all practiced tests exhibit a similar structure (Figure 8a). Top-0.2-m-thick surface soil needs fewer than 10 blows until reaching the anthropogenic deposits. At this point, blow count becomes more variable and layers deposited $0.2-1.5 \mathrm{~m}$ deep below the surface require $10-20$ blows (occasionally 30 ) to be penetrated. Below $1.5 \mathrm{~m}$ deep, penetration becomes more regular and blow count values oscillate between 5 and 10 and keep regular within each test (Table 5). Higher variability in the anthropogenic deposits, as indicated by values of standard deviation and covariance, is due to the fact that several layers were penetrated during the survey while only the lower quaternary terrace $(\mathrm{Q} 11)$ was affected.

Considering that raw data represented in figure $8 \mathrm{a}$ only considers the absolute depth of each test, disregarding the altitude a.s.l. of different penetration points, a second graph (Figure $8 \mathrm{~b}$ ) represents the 
curves of soil resistance according to this absolute altitude. There can be observed that the highest peaks are registered at c. $58 \mathrm{~m}_{\text {a.s. }}$, within a range of highly variable resistance between 56.2 and 59.3 $\mathrm{m}_{\text {a.s.l. }}$. Below $55 \mathrm{~m}_{\text {a.s.l. }}$, soil resistance becomes regular and stable at those levels interpreted as natural deposits. Areas with highest peaks are usually those where $\mathrm{CaCO}_{3}$-richer or coarser gravely layers are penetrated.

Regarding the difference between natural and anthropogenic strata, comparison between DPSH results and borehole logs led us to produce a third graph (Figure 8c) to represent the relation between regular resistance of natural soils more precisely, and also to assess the correlation between tests with similar elevations of the interface below anthropogenic deposits. This graph enables us to see that those tests where the elevation of natural deposits are very similar are well correlated and almost coincident. That is the case of surveys $17_{\text {out }}$ and $19_{\text {out, }}$ where the natural surface elevation is assumed to be at 57.2 and $58 \mathrm{~m}_{\text {a.s. }}$ respectively, and graphs are almost continuous. Graphs $4_{\text {out }}$ and $6_{\text {out }}$ show a very similar correlation with the natural surface identified at 55.7 and $55.5 \mathrm{~m}_{\text {a.s. }}$. The comparison between the values of the $10_{\text {out }}$ and $22_{\text {out }}$ tests is particularly interesting because the calculated elevation value of the natural surface is fully equivalent $\left(56.9 \mathrm{~m}_{\text {a.s. }}\right)$ and they beautifully overlap showing an equivalent resistance of the subsurface.

\section{DISCUSSION}

Interaction between archaeology and geology has been fructiferous for a long time and has provided valuable data regarding the exploration of new sites or areas with archaeological potential, the study of environments and landscapes and their human transformation, and the exploitation of natural resources or raw materials for different purposes (Pollard, 1999: 8). The geoarchaeological approach in Santa Margarida has enabled us to map the features and relief of ancient natural landscape (Figure 9) and to identify significant changes that occurred in the past, mostly due to human agency. Human interaction with the geosphere is a strong factor in landscape transformation (Wilson, 2011: 4-5), particularly from the Middle Age on (Price et al., 2011: 1060-1061), which might have some consequences on post-depositional affectations in the archaeological vestiges, as observed in Santa Margarida. Cross-section of deposit models in the archaeological site (Figure 9a-b), together with the isoline map for the buried land-surface of non-anthropogenic deposits (Figure 10), demonstrate to what extent the surrounding landscape of this site has been transformed.

Most recent transformation was due to the construction of the motorway, but this was not the only cause. The major refurbishment of this area carried out during the second half of the $20^{\text {th }}$ Century led to significant changes in the drainage network from the northern slope of the Coastal Mountain Range to the Anoia River, because the road cut the natural surface water flows of the torrential regime. Most of these natural torrents were redirected to subsurface drainage points projected at specific locations within the road itinerary. Nevertheless, this was not the case for Santa Margarida, as the torrent passing by this site appears to have disappeared earlier.

During the settlement's long endurance, several transformation episodes have occurred, usually with geomorphological and environmental impact. Written record of the acquisition of Sant Genís Priory together with Santa Margarida as its parish- by the Barcelonese merchant Joan Bolet in the $16^{\text {th }}$ Century informs about the refurbishment tasks carried out in the area (Baucells, 2007: 79). Probably at this time, the site experienced its first significant transformation, although the paleorelief still preserved much of its former appearance. The identified water flow, surrounding the church (Figure 10), was part of the site's layout and it received the settlement sewage water along a piping channel already in use during the late Middle Age (Figure 2c).

Thorough geomorphological transformation of this site took place across the $18^{\text {th }}$ and $19^{\text {th }}$ Centuries, when the area was terraced for farming purposes. A considerably thick landform assemblage of made ground was then deposited onto the alluvial plain resulting of disparate and concomitant natural and anthropogenic factors. According to the geographic information gathered by Francisco de Zamora in 1789 (Codina et al., 1992: 170-171), deforestation was severe at that time, which might have been a reason for acute weathering and sediment accumulation down through the mountain's slope. This provided ground material for artificial terracing and agricultural reworking of the area, but also 
required the channelization of some torrents, in order to conduct streams in the absence of such a pronounced slope, and the drainage and disappearance of some others. The torrent identified within the former land surface at the site was probably one of those.

Knowing the primal relief and features of this landscape has been crucial to understand more accurately a general trend observed within the archaeological record at this site. Most of the archaeological remains at the north and west walls of the church appeared eroded and occasionally displaced to the north with a regular inclination, particularly detected in burial disposition or building interfaces of destruction. Despite the terracing and levelling of the ancient torrent depression, post-depositional compaction of sediment gradually originated a slight displacement of the archaeological remains, particularly artefacts that tend to roll down to the torrent basin. Before discovering the existence of these depression or valley at the north of the site formed by the ancient water flow, there was no plausible explanation for the particular disposition of archaeological vestiges. Undoubtedly, this discovery has shed new light into the archaeological interpretation of post-depositional affectation, which increases the closer and deeper we get to this ancient torrent during fieldwork.

The differences in relief between the present-day surface and the buried land-surface of the natural landscape in the external surveyed area are not as explicit as within the archaeological site. The anthropogenic deposits herein reach a depth of $1-3 \mathrm{~m}$, the thinner deposits being those in the eastern area where boreholes $6_{\text {out }}, 7_{\text {out }}, 8_{\text {out, }}$ and $13_{\text {out }}$ are located, and the thicker packages of anthropogenic sediment those of the closest area to the archaeological site (boreholes $16_{\text {out, }} 19_{\text {out, }}$ and $24_{\text {out }}$ ). This suggests that the archaeological site has a well-defined perimeter.

The archaeological remains at the site are usually below a roughly 0.80 -m-thick stratum of farming ground mixed with the quarry waste (Rosenbaum et al., 2003: 408) of the motorway's building work. This surface layer is usually removed by machine under archaeological supervision. It is evenly spread throughout the entire area and is likely to cover most of the external surveyed extension as well, as suggested by some of the dynamic probe tests. High resistance peaks of surveys $4_{\text {out }}, 10_{\text {out }}, 19_{\text {out }}$, and $22_{\text {out }}$ were related to higher percentages of $\mathrm{CaCO}_{3}$ a $57-58 \mathrm{~m}$ deep. The presence of $\mathrm{CaCO}_{3}$-rich materials usually leads to excessively high DPSH values (MacRobert et al., 2011: 53). In our case, the presence of mortar fragments points towards the existence of this waste layer potentially equivalent to deposit $A_{1}$, at least in some areas. The presence of buried surfaces of vegetal soils $\mathrm{H}_{2}$ and $\mathrm{H}_{3}$ can correlate to some abandonment periods suggesting the archaeological potential of layers $B_{1}, A_{2}, B_{2}$, and $\mathrm{C}$, which are thinner and more heterogeneous. The presence of buried stable land surfaces provides an excellent opportunity to analyse for geochemical signatures of human occupation, which should be considered in further excavation in this area.

Given the results obtained in the external area (Figure 9c-e), one might wonder about the need of doing 25 surveys therein instead of fewer tests, as well as about the practicalities of dynamic probing. Actually, we are aware of the geotechnical criticism that dynamic tests received in some specialised literature on this topic, usually because of presumed poor repeatability and accuracy (MacRobert 2017: 11, Broms \& Flodin, 1988). As archaeologists ourselves, we took into account a few considerations to mitigate the weaknesses of DPSH: first, that dynamic probe is an economic an easy test that might be practical for archaeological purposes, which were not related to engineering assessment of soil suitability for other more compromising activities. It should be noted that the parameters measured during geotechnical investigation differ significantly from the parameters required by the geoarchaeologists (Bates \& Bates, 2000: 847). Second, that borehole logs and subsequent deposit modelling were the main criteria to assess the archaeological potential of the site and, hence, those quantitative and qualitative data allowed for a more comprehensive discussion of soil resistance trends and its interpretation, as considered above and as required also in geotechnical approaches. Third, that soil variability is a complex attribute resulting from many disparate sources of uncertainties, particularly when soil data from different geologic units are mixed (Phoon \& Kulhawy 1999: 614). That is why statistical examination of DPSH results, led us to calculate COV for anthropogenic deposits and the quaternary terrace separately.

The successful application of deposit modelling strategies (Carey et al., 2017 \& 2019, Bates \& Bates, 2000 ) inside the site's enclosure during a first stage of research encouraged us to survey a nearby forest 
extension in order to determine the archaeological potential of the area. The stratigraphic complexity of the archaeological site, determined in 2011 by 12 borehole logs separated a medium average of 25 $\mathrm{m}$ between each two of them, suggested the same strategy for the external survey. Presuming a similar degree of complexity, we considered that recording the subsurface stratigraphy required a similar amount of tests instead of fewer because a lower density of borehole information might have compromised the projection of landscape blocks (Bates \& Bates, 2000: 849); actually, it would have not. Nevertheless, it is not possible to know what happens subsurface in the absence of other nonintrusive methods available, due to the poor contact with the ground surface (Sarris et al., 2018: 231232). Hence, prospecting this wooded area also challenged us to search for effective techniques to assess the archaeological interest of the area. As Carey et al. pointed out (2017: 660), geoarchaeological deposit modelling does not attempt to predict where the archaeological remains might occur, but instead seeks to define the archaeological potential for a landform assemblage to contain cultural remains. Accordingly, the results obtained have fulfilled our objective of recording a general layout of the archaeological potential in the area.

Although GPR surveys carried out in 2010 and 2011 provided useful results (Sala et al., 2010 \& 2011), there were still some anomalies of difficult interpretation, probably due to the specific features of an alluvial environment (David et al., 2008: 16). In those contexts, the use of geophysical methods, as part of a more complex multidisciplinary approach to get a better comprehension of subsurface stratigraphy, is a topic that geoarchaeological literature has frequently addressed (Bates \& Bates, 2000; Challis \& Howard, 2006: 231; Shillito et al., 2019 [and references therein]; Goldberg \& Aldeias, 2018). Suggested procedures in these alluvial scenarios usually encourage the definition of hierarchical approaches in which methods for landscape visualization and archaeological prediction are settled according to the particular scale the project requires (Challis \& Howard 233-235). Even in non-alluvial environments, multi-criteria methodological decisions are encouraged and geological or lithological variables required as part of a holistic approach to the past (Nsanziyera et al., 2018: 7-8). The approach developed in Santa Margarida contributes to this up-to-date state of the art as a valuable study case, and it might offer experiences and feedback about the borehole logging approach in similar areas in Spain or beyond.

The interpretation of the data obtained has also benefited from the determination of landform sediment assemblages (Layzell \& Mandel, 2019). These are underlying genetically related packages of sediment and associated soils with predictable age relationships. Bearing in mind that the archaeological record is a component of the sedimentary record, physical processes that remove, modify or bury sediments control the preservation and visibility of the record of the human past (Layzell et al., 2018: 1; Bettis et al., 1996: 2). Identifying the stratigraphy of torrent flows and river terraces at this site in particular -there at least four river terraces known in the area of Martorell-, distinguishing the Peistocene bedrock, and knowing the features of these alluvial landform assemblages informs about the potential areas in which earlier archaeological vestiges, if any, might have been preserved (Howard \& Macklin, 1999). To that extent, geomorphological deposit modelling in Santa Margarida did not provide any evidence for the presence of archaeological vestiges within the floodplain sediment under the artificial ground. Certainly, given the limited exposure that a core provides, the physical analysis and description of core data is, in general, a poor way to identify buried archaeological materials/features. However, we know at this point that the site has almost no potential in its northern area, since the garnet shale and Buntsandstein sandstone outcrops are closer to the surface.

Santa Margarida's long history has set a deep imprint on its surrounding landscape, understanding it as complex and wide-ranging entity that includes landform and environmental issues, but also the way in which human beings interact with them (Thomas, 2001). Santa Margarida's modern landscape where a massive motorway broke the territorial unity of the Priory and its seven-century-old buildingsis just the surface expression of these underlying processes of transformation (Price et al., 2011: 1059). Understanding the reality beneath required a wider geomorphological approach that fulfilled our initial aim of scheduling a more precise excavation plan, but it has also shed some light on the medieval and modern evolution of this site, which helped us understand how peasant agency and the landlords' interests interacted. 


\section{CONCLUDING REMARKS AND FUTURE PROSPECTS}

Geoarchaeological examination of Santa Margarida's subsurface has proved to be an effective way of defining the interface elevation between anthropogenic deposits and natural packages of alluvial sediment. This has opened brand new lines for data interpretation and has led to the discovery of ancient water flows, shedding new light on the primal layout of this site. In positively identifying this natural or geological horizon, we have now a broad idea about the total depth and volume of the excavation area before the fieldwork takes place, and we have obtained valuable information for interpreting postdepositional affectation of archaeological vestiges more precisely.

A combined approach of borehole logging, core sampling and dynamic probing on the basis of previous non-intrusive GPR testing has turned out to be a useful strategy for archaeological deposit modelling. A ten-year-long survey plan within a consolidated research project has allowed us to know the features of alluvial terraces and sediments therein, which enables us to decide to what extent the archaeological excavation is completed or not, and to design more cost-effective archaeological fieldwork schedules.

Further research in Santa Margarida is expected to complete the diachronic view of the landscape transformation in a rural area of Catalonia, from the late antique period to the present day. After a long research plan focussed on the site's layout and evolution, now it is time for a spatial turn attempting to understand the interaction between Santa Margarida's parish and the Monastery of Sant Genís, and the role of both as agents for construction of a feudal territory in Medieval Catalonia and its lordship endurance.

\section{ACKNOWLEDGEMENTS}

The Catalan Government (Generalitat de Catalunya) funded this research as part of two consecutive Archaeology and Paleontology 4-year-long research projects (2014/100608 and CLT009/18/00036 DGPC/exp. 35). The Town Council of Martorell generously contributes to the archaeological on-site research in Santa Margarida providing financial support. This study is part of the current research tasks carried out by the Medieval and Postmedieval Archaeology Research Group GRAMP.-UB (2017SGR-833-GRC) at the University of Barcelona, of which some of the authors are members, and it is included in our Landscape Archaeology research line. The authors wish to thank field technicians involved in practical development of tests and logging, and also Ms Noemí Travé for language editing and review.

\section{AUTHOR'S CONTRIBUTION}

Conceptualization, A.M.M.; Data curation, J.M.T.R, P.d.F.B. and J.S.D; Funding acquisition, E.T.A., P.d.F.B. and A.M.M.; Investigation, J.M.T.R and E.T.A.; Methodology, J.M.T.R, and A.M.M.; Supervision, J.M.T.R, and J.S.D.; Validation, J.M.T.R; Writing - original draft and figures, E.T.A. and J.M.T.R; Writing - review and editing, P.d.F.B., A.M.M. and J.S.D. All authors have read and agreed to the published version of the manuscript.

\section{DATA AVAILABILITY STATEMENT}

The data that support the findings of this study are available on request from the corresponding author. The data are not publicly available due to privacy or ethical restrictions. They are part of unpublished technical reports (Tella 2011, 2019) kept in the Centre d'Estudis Martorellencs' archive.

\section{REFERENCES}

Artz, J. A. (2006). Decision Support Model for Assessing Archaeological Survey Needs for Bridge Replacement Projects in Iowa. Iowa City: Office of the State Archaeologist. The University of Iowa. 
American Society for Testing and Materials (2017) ASTM D3550 / D3550M-17, Standard Practice for Thick Wall, Ring-Lined, Split Barrel, Drive Sampling of Soils, West Conshohocken (PA, USA): ASTM International, doi: 10.1520/D3550_D3550M-17

Bates, M. R., Bates, C. R. (2000). Multidisciplinary approaches to the geoarchaeological evaluation of deeply stratified sedimentary sequences: examples from Pleistocene and Holocene deposits in Southern England, UK. Journal of Archaeological Science, 27: 845-858.

Baucells, J. (2007). El Priorat de Sant Genís de Rocafort (Martorell). Martorell (Spain): Centre d'Estudis Martorellencs.

Bettis, E. A. III., Quode, D. J. Kemis, T. J. (1996). Hogs, bogs, \& logs: Quaternary Deposits and Environmental Geology of the Des Moines Lobe. Bureau Guiebook Series N. 18. Iowa City: Iowa Geological Survey.

Broms, B. B., Flodin, N. (1988). History of soil penetration testing. Proceedings, 1st International Symposium on Penetration Testing, ISOPT-1, 20-24 March, Orlando, FL. Rotterdam: AA Balkema, $157-220$.

Burmister, D. M. (1949). Principles and techniques of soil identification. Proceedings of the Annual Highway Research Board Meeting. National Research Council. Washington, DC 29, 402-434.

Campana, S. (2009). Archaeological site detection and mapping: Some thoughts on differing scales of detail and archaeological 'non-visibility'. In Campana, S., \& Piro, S. (eds.) Seeing the Unseen Geophysics and Landscape Archaeology. London: CRC Press Taylor \& Francis Group, 5-26.

Carey, Ch., Howard, A. J., Jackson, R., Brown, A. (2017). Using geoarchaeological depòsit modelling as a framework for archaeological evaluation and mitigation in alluvial environaments. Journal of archaeological science: reports, 11: 658-673.

Carey, Ch., Howard, A. J., Corcoran, J., Knight, D., \& Heathcote, J. (2019). Deposit modeling for archaeological projects: Methods, practice, and future developments. Geoarchaeology, 34, 495-505. doi: $10.1002 /$ gea. 21712

Casagrande, A. (1948). Classification and Identification of Soils. Transactions of the American Society of Civil Engineers, 113, 901-930.

Challis, K., Howard, A. J. (2006). A review of trends within archaeological remote sensing in alluvial environments. Archaeological prospection, 13: 231-240.

Codina, J., Moran, J., Renom, M. (1992). El Baix Llobregat el 1789. Respostes al qüestionari de Francisco de Zamora. Montserrat: Curial Edicions Catalanes / Publicacions de l'Abadia de Montserrat.

David, A.; Linford, N., \& Linford, P. (2008). Geophysical survey in archaeological field evaluation. Portsmouth: English Heritage.

Farreny, M., Mauri, A., Navarro, R. (2012). El projecte de recerca i recuperació de Santa Margarida de Martorell. In Patrimoni, història local i didàctica. Homenatge a Jaume Codina. Actes de les VI jornades del Patrimoni del Baix Llobregat. Sant Feliu de Llobregat (Spain): Consell Comarcal del Baix Llobregat, 362-371.

Francovich, R. (2004). Villagi nell'altomedioevo: invisibilità sociale e labilità archeologica. In Valenti, M. (ed.) Insediamento altomedievale nella campagne toscane. Paesaggi, popolamento e villaggi tra VI e X secolo, Florence, 9-22.

García-Gains, R., Frankenstein, S. (2015). USCS and the USDA Soil Classification System. Development of a Mapping Scheme. U.S. Army Engineer Research and Development Center, Vicksburg.

Goldberg, P., Aldeias, V. (2018). Why does (archaeological) micromorphology have such little traction in (geo)archaeology? Archaeological and Anthropological Sciences, 10: 269-278. doi: 10.1007/s12520-016-0353-9. 
Highway Research Board, HRB. (1952). Mapping and subsurface exploration for engineering purposes. Bulletin 65. National Academy of Sciences - National Research Council, Washington.

Howard, A. J., Macklin, M. G. (1999). A generic geomorphological approach to archaeological interpretation and prospection in British river valleys: a guide for archaeologists investigating Holocene landscapes. Antiquity, 73: 527-541.

Kettler, T. A., Doran, J. W., Gilbert, T. L. (2001). Simplified Method for Soil Particle-Size Determination to Accompany Soil Quality Analyses. Publications from USDA-ARS/UNL Faculty, 305. https://digitalcommons.unl.edu/udsaarsfacput/305.

Kokinou, E. (2015). Geoarchaeology: a Review in Techniques. In Sarris, A. (ed.) Best practices of geoinformatic tecnologies for the mapping of archaeolandscapes. Oxford: Archaeopress, 209-217.

Layzell, A. L., \& Mandel, R. D. (2019). Using soil survey data as a predictive tool for locating deeply buried archaeological deposits in stream valleys of the Midwest, United States. Geoarchaeology, 34, 80-99. doi: 10.1002/gea.21707

Layzell, A. L., Mandel, R. D., Ziska, C. L., \& Bozell, J. R. (2018). Systematic Approach to Identifying Deeply Buried Archeological Deposits. Nebraska Department of Transportation Research Reports, 202. Retrieved from https://digitalcommons.unl.edu/ndor/202

MacRobert, C. J. (2017). Interpreting DPSH penetration values in sand soils. Journal of the South African Institution of Civil Engineering, 59/3: 11-15.

MacRobert, C. J., Kalumba, D., \& Beales, P. (2011). Correlating Standard Penetration Test and Dynamic Probe Super Heavy penetration resistance values in sandy soils. Journal of the South African Institution of Civil Engineers, 53/1: 46-54.

Mauri, A. (1988). Les excavacions arqueològiques a la Plaça de l'Església (Martorell). Quatre Ratlles, Quaderns d'Estudis Locals, 2. Martorell (Spain): Centre d'Estudis Martorellencs.

Navarro, R., Mauri, A. (1993). Santa Margarida de Martorell: la transició de l'antiguitat tardana al món medieval. In IV Congreso de Arqueología Medieval Española, Alicante (Spain): Diputación Provincial, 341-344.

Navarro, R., Mauri, A., (1997). La ceràmica medieval de Martorell. In González, A. (ed.). La ceràmica medieval catalana. El monument, document, Quaderns científics i tècnics 9, Barcelona: Diputació de Barcelona, 89-100.

Nsanziyera, A. F., Rhinane, H., Oujaa, A., \& Mubea, K. (2018). GIS and Remote-Sensing Application in Archaeological Site Mapping in the Awsard Area (Morocco). Geosciences, 8, 207. doi:10.3390/geosciences 8060207

Phoon, K. K., Kulhawy, F. H. (1999). Characterization of geotechnical variability. Canadian Geotechnical Journal, 36/4: 612-624.

Pollard, A. M. (1999). Geoarchaelogy: an introduction. In Pollard, A. M. (ed.). Geoarchaeology: exploration, environments, resources. London, Geological Society, Special Publications, 165, 7-14.

Price, S. J., Ford, J. R., Cooper, A. H., Neal, C. (2011). Humans as major geological and geomorphological agents in the Anthropocene: the significancee of artificial ground in Great Britain. Philosophical Transactions of the Royal Society A, 369: 1056-1084.

Quirós-Castillo, J. A. (2011). ¿Por qué excavar grandes extensiones? Arqueología de los despoblados alaveses y estudio de la aldea de Zornoztegui (Salvatierra-Agurain). In Agurain 1256-2006: Congreso 750 aniversario de la fundación de la villa de Salvatierra. Salvatierra (Spain): Ayuntamiento de Salvatierra, 379-402.

Quirós-Castillo, J. A., \& Nicosia, C. (2019). Reconstructing past terraced agrarian landscapes in the Ebro valley: The deserted village of Torrentejo in the Basque Country, Spain. Geoarchaeology, 34, 684-697. doi: 10.1002/gea.21730 
Reynolds, A. (2003). Boundaries and settlements in later Sixth to eleventh-century England. In Griffiths, D., Reynolds, A., Semple, S. (eds.). Anglo-Saxon Studies in Archaeology and History, 12, Oxford: University School of Archaeology, 98-136.

Rosenbaum, M. S., McMillan, A. A., Powell, J. H., Cooper, A. H., Culshaw, M. G., Northmore, K. J. (2003). Classification of artificial (man-made) ground. Engineering Geology, 69: 399-409. doi: 10.1016/S0013-7952(02)00282-X.

Rząsa, S., Owczarzak, W. (2013). Methods for the granulometric analysis of soil for science and practice. Polish Journal of Soil Science, XLVI/1: 1-50.

Sala, R., Garcia, E., Tamba, R. (2010 \& 2011). Prospecció geofísica per a la descripció de l'entorn arqueologic. Santa Margarida de Martorell. Technical Reports. Martorell (Spain): SOT Prospecció Arqueològica.

Sarris, A., Kalayci, T., Moffat, I., \& Manataki, M. (2018). An Introduction to Geophysical and Geochemical Methods in Digital Geoarchaeology. In Siart, C., Forbriger, M., \& Bubenzer, O. (eds.), Digital Geoarchaeology. New Techniques for Interdisciplinary Human-Environmental Research. Switzerland: Springer, 215-236, doi: 10.1007/978-3-319-25316-9_14

Schofield, J. (1991). Interpreting artefact scatters. Contribution to ploughzone archaeology, Oxford: Oxbow Monographs 4.

Shillito, L.-M., Blong, J., Sawyer, A. \& Mackay, H. (2019). Geoarchaeology from landscapes to material culture: Papers from the 7th Developing International Geoarchaeology conference. Geoarchaeology, 34, 377-379. doi:10.1002/gea.21742

Spagnoli, G. (2007). An empirical correlation between diferent dynamic penetrmeters. EJGE Electronic Journal of Geotechnical Engineering, 12C: 1-12.

Stein, J. K. (1990). Archaeological Stratigraphy. The Geological Society of America. Centennial Special Volume, 4: 513-523.

Travé, E., Navarro, R., Mauri, A., Farreny, M., Del Fresno, P., Socorregut, J. (2019). De l'església paleocristiana a la sagrera medieval: Transformacions estructurals i ordenament intern del Jaciment de Santa Margarida (Martorell, Barcelona). In López Vilar, J. (ed). Actas del $4^{\circ}$ Congreso Internacional de Arqueología del Mundo Antiguo. VII Reunión de Arqueología Cristiana Hispánica, Tarragona: URV, 181-188.

Vigil-Escalera, A. (2010). Formas de parcelario en las aldeas altomedievales del sur de Madrid. Una aproximación arqueológica preliminar. In Kirchner, H. (ed.) Por una arqueología agraria. Perspectivas de investigación sobre los espacios de cultivo en las sociedades medievales hispánicas. BAR International Series 2062. Oxford: Archaeopress.

Wilson, L. (2011). The role of geoarchaeology in extending our perspective. In Wilson, L. (ed.) Human Interactions with the Geosphere: The Geoarchaeological Perspective. London, Geological Society, Special Publications, 352, 1-9. doi: 10.1144/SP352.1

[dataset] Tella, JM. (2011). Estudi geològic al jaciment arqueològic de Sta. Margarida. T.M. de Martorell. Report EG2211. Martorell: Centre d'Estudis Martorellencs.

[dataset] Tella, JM. (2019). Estudi geologic al jaciment arqueològic de Sta. Margarida. T.M. de Martorell. Report EG0617. Martorell: Centre d'Estudis Martorellencs. 


\section{FIGURE CAPTIONS}

Figure 1. Location map of the archaeological sites mentioned in this paper (a-c) and layout plan of the Early Christian and Romanesque Church of Santa Margarida (d).

Figure 2. South (a) and north (b) views of the Romanesque church of Santa Margarida and aerial view (c) of the excavation trench enlarged in 2012.

Figure 3. Geological map of the site's environment with main orographic accidents labelled.

Figure 4. Detailed plan of the site's enclosure and the external surveyed area with borehole location represented according to the testing techniques put into practice.

Figure 5. Stratigraphic columns for different borehole groups representing the layering sequence at the site. Coarser fractions of anthropogenic deposits A, B, and C, are illustrated with microphotographs in hand specimen.

Figure 6. PSD graphs of Quaternary alluvial deposits of medium to fine silt related to the lower terrace in the external surveyed area (top) and coarser bimodal packages of sediment deeper buried in the lower or middle terraces (bottom). Graphs at left represent percentages of each fraction and graphs at right are accumulative.

Figure 7. PSD graphs of anthropogenic sediment layers A, B, C identified at the external surveyed area (top) and Ad levels of the archaeological enclosure (bottom). Like in the previous figure, graphs at left represent percentages of each fraction and graphs at right are accumulative.

Figure 8. Results of dynamic probing test for the analysis of soil resistance to penetration. Graph at left illustrates raw data of DPSH blow count related to absolute depth of each borehole (a). At right, graphs compare results between them according to the altitude expressed as $\mathrm{m}$ above the sea level (a.s.l.) (b), and the elevation of the interface between antropogenic and natural deposits (c).

Figure 9. Cross section of deposit models from the archaeological site of Santa Margarida (a-b) and the external surveyed area (c-e). In NS cross sections inside the archaeological area, anthropogenic deposits lay upon Miocene bedrock and Quaternary alluvial deposits. Deposit modelling in the nonexcavated external area allowed us to distinguish sublayers within the anthropogenic deposit together with ancient soil surfaces.

Figure 10. Isoline map of the buried land-surface of the Quaternary deposits, showing the primal flow of the torrent in Santa Margarida before being drained.

\section{TABLE CAPTIONS}

Table 1: Location and methods applied for geological surveying at the Site of Santa Margarida

Table 2: Highway Research Board (HRB) Classification of Soil (HRB, 1952).

Table 3: Unified soil classification system (USCS) (Casagrande, 1948).

Table 4: Summary table of geotechnical features of identified strata according to core samples examined, expressed as mean values of different variables explored. Standard deviation is provided in brackets and italics.

Table 5: DPSH data variability calculated for anthropogenic and natural deposits. 